\title{
THE IMPLEMENTATION OF NATIONAL STANDARD-BASED CURRICULUM IN PRIVATE ISLAMIC HIGHER EDUCATION: LEADERSHIP IMPACT
}

\section{A. Rusdiana}

Universitas Islam Negeri (UIN) Sunan Gunung Djati Bandung

Jl. A. H. Nasution No. 105 Cibiru, Bandung, Jawa Barat, Indonesia 40614

Email: rusdiana61@gmail.com.

\section{Nasihudin}

Universitas Islam Negeri (UIN) Sunan Gunung Djati Bandung

Jl. A. H. Nasution No. 105 Cibiru, Bandung, Jawa Barat, Indonesia 40614

Email: enspono20@gmail.com.

Received: 02, 2018. Accepted: 06, 2018. Published: 06, 2018.

\begin{abstract}
The implementation of KKNI (Kerangka Kualifikasi Nasional Indonesia/national standard-based curriculum), especially in PTKIS (Perguruan Tinggi Keagamaan Islam Swasta/Private Islamic Higher Education) demands the role of its study program leaders. The purpose of this study was to explore the implementation of KKNI curriculum on several perspectives: role, performance, teaching steps, understanding factors related to the distribution KKNI, and impact to education in Indonesia. This study used a descriptive qualitative method, including interview, observation, and documentation as technique for collecting data and triangulation technique for ensuring data validity. The results indicated that the performance of eight heads of PAI (Pendidikan Agama Islam/Islamic education) Study Program was not in optimum condition as a determinant of the direction, representative of spokesperson, communicator, mediator, and integrator. The implementation of the curriculum was also not effective yet. Then, the factors that influence the implementation are the lack of resources, time, campus ethics, knowledge support, professional interests and attitudes. To understand this condition, we also investigated the impact of knowledge, in which the result showed no information regarding what the policy/program offers, what the target group needs, and why the average student's score is still low. National accreditation, in the eight PAI Study Programs, did not reach the excellence category. Thus, the performance on the study program has not been accountable and will have implications for the weakness of social legitimacy.
\end{abstract}

Keywords: Accountable, Integrated, Leadership, Professional.

\section{ABSTRAK}

Implementasi kurikulum berbasis KKNI, khususnya di PTKIS menuntut peranan ketua program studi. Oleb karenanya, makalah ini bertujuan untuk memaparkan peranan dan performa ketua program studi serta langkahlangkah yang mereka ambil dalam mengimplementasikan kurikulum berbasis KKNI, faktor-faktor dan dampak pada implementasi kurikulum berbasis KKNI. Penelitian menggunakan metode deskriptif kualitatif dengan melakukan wawancara, observasi, dan dokumentasi sebagai teknik pengumpulan data, serta menggunakan teknik. triangulasi untuk. keabsahan datanya. Hasilpenelitian menujukan babwa kinerja dari delapan Ketua Program Studi PAI belum optimal memerankan fungsiny a sebagai penentu arah, wakil juru bicara, komunikator, mediator, dan integrator. Implemenntasi kebijakan kurikulum perguruan tinggi berbasis KKNI di delapan Program Studi PAI belum efektif. Faktor-faktor yang mempengarubi penerapan kurikulum perguruan tinggi berbasis KKNI adalab kurangnya sumber daya, waktu, etos kampus, dukungan pengetahuan, minat dan sikap profesional. Dampak pengetabuan belum memperlibatkan tandatanda adanya kesesuaian antara apa yang ditawarkan oleb kebijakan/program dengan apa yang dibutubkan oleh kelompok sasaran dan rata-rata indeks prestasi komulatif mahasiswa masib rendah, akreditasi nasional di delapan pogram studi P AI belum mencapai kategori unggul. Dengan demikian kinerja program studi belum akuntabel dan akan berimplikasi pada semakin lemahnya legitimasi sosial.

Kata Kunci: Akuntabel, Professional, Kepemimpinan, Terintegrasi. 


\section{INTRODUCTION}

PTKIS as an institution nurtured and developed by the Religious Affairs Ministry of the Republic Indonesia, has a major contribution towards the development of Indonesian human resources (Hashim \& Langgulung, 2008). Since Indonesia is the world's largest Islamic country, the ongoing question for the Islamic community has been how to create a strong, pious, and faithful Islamic society in the context of a modernizing, globalizing, and secular state. Thus, developing a hybrid educational system in Islamic school has outwardly supported the national development policies while striving to firmly establish Islamic values as the foundation for public life in Indonesia (Lukens-Bull, 2001). Although this perspective can be obtained from international view about Indonesia, many Indonesian people considered that Islamic school has not yet improved the socio-economic and political condition in Indonesia. Further, PTKIS is less successful in developing its vision, mission, and responsibilities (Amirrachman, Syafi'i, \& Welch, 2008). This statement cannot be denied, considering the value of most of PTKIS study programs has low score based on national standard for university accreditation (BAN-PT) (Ainin, 1992). That fact shows that PTKIS is still not accountable for improving Indonesian students.

The problems in the low quality of PTKIS does not happen only in Indonesia but also in other Islamic countries, such as Malaysia (Hashim \& Langgulung, 2008), Bangladesh (Asadullah, Chakrabarti, \& Chaudhury, 2012), Iran (Shorish, 1988), etc. Specifically, the main negative perspective is found in the negative association between madrasa attendance and test scores (Asadullah, 2015). PTKIS are disproportionately attended by children from relatively disadvantaged backgrounds. Non-random sorting of children into Islamic faith schools by family background and cognitive ability together can give a negative appearance. Indeed, the possibility of non-random sorting into religious schools has been at the center of the current debate over superiority of public/national school as well as Catholic schools (Asadullah et al., 2012). Although the Islamic school such as PTKIS correlates with the macroeconomic condition movement (Rahman, 2010), the movement is not yet found.

Although above reports showed the way for solving problems for PTKIS in Islamic countries, there is no specific explanation about condition in Indonesia. The main problems hampering the realization of the accountability of PTKIS in Indonesia included several factors. These factors have to be faced for improving the quality of PTKIS. The problems are: (1) management and leadership; (2) curriculum; (3) lecturers; (4) lecturing process; (5) student input; (6) learning facilities; (7) the environment; (8) operational funds; (9) low ability of lecturer in doing scientific research; (10) low ability of lecturer in writing research report or article based on the interesting research results; and (11) the lack of attention to the leadership to disseminate the results of research that have been done by lecturers and students (Hadijaya, 2015). These factors become the challenges in almost all PTKIS and one PTKIS has different factors to be appeared, influencing the quality of the school and students' ability.

Further, in Indonesia, the factor must be added with the demands on the policy of applying the national standard for higher-education curriculum, namely KKNI. Each study program has to clarify the graduate profile expected through study tracking, feasibility study, and analysis in the community. Indeed, when this condition is combined with above factors, serious problems will be created in the societies' opinion and perspectives.

Based on the above limitations, it becomes an interesting phenomenon to be studied further considering the condition of PTKIS. For this reason, here, the objective of this study was to explore the leadership practice with the study program and to illustrate their role and issues in delivering their institution to be accountable. As a model of this PTKIS, we used Kopertais (Koordinasi Perguruan Tinggi Agama Islam/Association of Islamic Higher Education) Region II of West Java and Banten since this PTKIS has not fully understood whether the 
school has implemented KKNI-based curriculum of higher education or not. There are many questions discussed here: (1) What is the role and performance as the study program leader in implementing the KKNI-based curriculum of higher education? (2) What are the steps in implementing KKNI-based curriculum of higher education? (3) What are the factors that influence the application of KKNI-based curriculum of higher education? (4) What is the impact upon the implementation of KKNI-based curriculum of higher education?

Based on the above questions, we believed that the new information will be obtained for improving quality of PTKIS in Indonesia, specifically for West Java and Banten area.

\section{METHOD}

This research was conducted using a qualitative method based upon the paradigm of postpositivism. This study used no statistical analysis but focused on portraying and categorizing accounts. Natural objects that were considered social phenomena during Islamic religious education were the focus of research and then interpreted through a phenomenological approach, in which the researcher was not preoccupied, abandoning his beliefs, stigma, or suspicion of objects. The researcher is an outsider to avoid prejudices, catch authentic phenomena, and he does not interfere before collecting data. The code of ethics prior to the research is conducted by obtaining the permit issued by the authorities and the approval letter shown to the respondent.

A comparative approach was used to show in detail the information of two or more phenomena. The comparative study uses a descriptive approach to find subject suitability and focus on differences and similarities between subjects.

The research is conducted on the similarities and differences in promoting the curriculum of higher education based on KKNI. The data was obtained from Kopertais Region II of West Java and Banten (See Figure 1). Primary data are obtained from eight heads of PAI, eight heads of PAI project supervisors; eight lecturers from PAI, eight students, and eight parents/communities from the eight PAI programs. Secondary data include literature studies and relevant documents and collect data from research subjects by going through a series of observations, interviews, and documentation. The results are then analyzed by means of reduction, display, and verification, and then divided into categories. The view is meant to expose data into the theme after the categorization is complete.

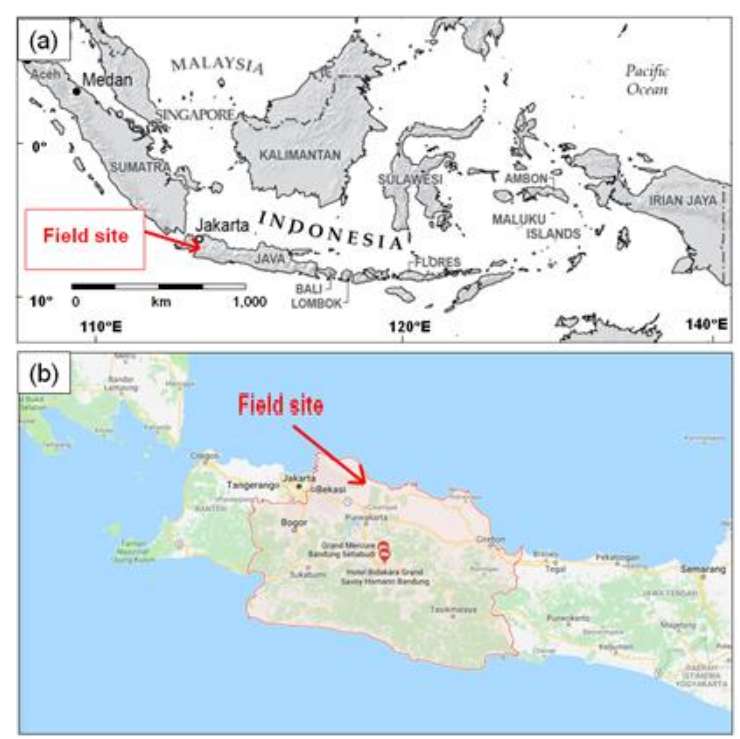

Figure 1. The Field of the Measurement Site. Figure (a) The Location of the Field Site in Indonesia. Figure (b) The Exact Area That is Evaluated. Figure was adapted from reference (Abdullah et al., 2018). 


\section{RESULTS AND DISCUSSION}

\section{Leaders' Roles, Functions and Duties in Private Islamic Higher Education}

The role of educational management is to organize and to locate a person in certain positions (Schein, 2003). Meanwhile, leadership is concerned with a deliberate process as a person to emphasize his strong influence on others to guide, structure, facilitate activities within groups or organizations (Kozlowski \& Ilgen, 2006). It is a process affecting the activity with a person or group of people to achieve goals in certain situations (Gollwitzer, 1999). Thus, leadership is one of the abilities to influence others to achieve certain goals (Conger \& Kanungo, 1987). The leadership functions include several aspects: (a) leader as direction determinants; (b) the leader as the deputy and spokesman of the organization; (c) the leader as effective communicators; (d) the leader as mediator; (d) the leader as integrators (Klerkx \& Aarts, 2013).

\section{Private Islamic Higher Education}

PTKIS is an institution nurtured and developed by the Ministry of Religious Affairs of the Republic of Indonesia. Institutionally, it is part to the development of Islamic Higher Education, which consists of STAI (Sekolah Tinggi Agama Islam/School of Islamic Religion), IAIN (Institut Agama Islam Negeri/State Islamic Institute), and UIN (Universitas Islam Negeri/State Islamic University (Barton, 1997). Based on Government Regulation of Republic Indonesia No. 4 Year 2014 Article 1, paragraph 6, it is affirmed that private universities, hereinafter abbreviated to PTS (Perguruan Tinggi Swasta/Private Higher Education) are universities established and/or organized by the public. PTKIS and Islamic school are classified as PTS.

The existence and success of a higher-education institution rely heavily on inputs, processes, outputs, and outcomes, in which all these stages must be controlled by a capable leader to the field (Stufflebeam, 2001). The leaders in higher education can actually be divided into two groups: (a) structural leader leaders such as deans and staff, rectors and staff; and (b) scientist leaders who lead science groups, respected by peers, having scientific followers, students, researchers, or the general public (Walsh, Tushman, Kimberly, Starbuck, \& Ashford, 2007).

\section{The Leaders' Task in Islamic Higher Education Institutions}

The Dean, as the head of the study program or a similar higher-education official, is the direct supervisor of the lecturer who has the duty to direct and conduct the guidance to the lecturer in his position as the person in command of the implementation of faculty staff job at the faculty level or the department or similar position (Shartle, 1946). The Dean has the following tasks; (a) distribute fairly the teaching task to the lecturer; (b) allocate time for lecturers to carry out education and teaching and research tasks with weight of at least 9 (nine) credits each semester. Dean, head of department, head of study program or similar higher-education official must propose faculty lecturer who cannot fulfill the minimum weight of education and teaching task to Rector or similar higher-education leader to be assigned in faculty or other majors in internal higher education or on higher education; (c) at the beginning of the semester, request the lecturers to collect the documents (Higgins, 2009). The document is used as the benchmark of lecturer workload arrangement in the coming semesters. Technical document collection may be designated through the quality assurance implementing unit, or similar institutions. The Dean, the head of the department, the head of the study program or the leader of the same higher education reprimanded orally or in writing to the lecturer who has not made/submitted the document in accordance with the stipulated deadline (Sarros et al., 1999). Technical provisions in this matter are regulated through the rules of their respective college leaders (Mazmanian \& Sabatier, 1980). 


\section{Implementation of KKNI-Based Curriculum of in Islamic Higher Education}

The higher-education curriculum is developed by each university with the orientation of the Indonesian National Qualification Framework and refers to the National Standards of Higher Education. Directorate General of Learning and Student Affairs in 2016, has designed a number of programs related with the development and application of curriculum in universities (Rany, Zain, \& Jamil, 2012). The implementation of the curriculum is expected to produce qualified graduates that are relevant to national development, including the needs of highly skilled and skilled workers in the industrial world (Raybould \& Wilkins, 2005). The higher-education curriculum is developed by each higher education with reference to the National Standards of Higher Education for each study program, which includes the development of intellectual intelligence, noble character, and skills (Subotnik, OlszewskiKubilius, \& Worrell, 2011).

This national instruction is contained in the Minister of Education and Culture Regulation No. 73 of 2013 on the application of national standard for the field of higher education (Ylimaki \& Jacobson, 2013). This can be a derivative regulation from Presidential Regulation No. 8/2012, which explains that Indonesia National Qualification Framework is a framework of competency qualification that can pair, equalize and integrate between the field of education and the field of job training and work experience in the framework of recognition work competence in accordance with the structure of work in various sectors (Podzimek, 2014).

Based on these two policies, each study program is required to reformulate the curriculum that really leads to the need (Portin, Schneider, DeArmond, \& Gundlach, 2003). From the perspective of Indonesia national standard, the curriculum of each course should clarify the graduate profile and the achievement of expected competency (Oliver et al., 2008).

The curriculum development implementation cycle orients to the Indonesian National Qualification Framework and refers to the National Standards of Higher Education. This cycle is rejected by the Directorate General of Learning and Student Affairs in 2016, as follows: (1) determining graduated and learning achievement profile; (2) selecting and assembling the study materials; (3) preparing courses, curriculum structure, and determine credit; and (4) preparing lesson plans (Chun \& Evans, 2016).

The Graduate Competency Standard (SKL/Standar Kompetensi Lulusan) is part of the national standard of education, which is the minimum graduate competency criteria applicable throughout the jurisdiction of the Unitary State of the Republic of Indonesia. SKLs that are applied into competency standards and basic competence (KD/Kompetensi Dasar) subjects are used as assessment guidelines. The preparation of SKL of the educational units is a priority agenda because it becomes a reference for the preparation of other education standards.

\section{The Characteristics of Successful Implementation of Curriculum Policies}

Policy management expert considers that a program will be successfully implemented if there are conformities of the three elements of program implementation namely; (1) suitability between the program and the beneficiary; (2) conformity between the program and the implementing organization; and (3) suitability between the beneficiary group and the implementing organization.

\section{Factors Affecting the Implementation of Curriculum}

Meanwhile, researchers suggested there are three factors that influence the implementation of the curriculum: principal support, peer support teachers, and internal support within the classroom (Jennings \& Greenberg, 2009). The development of a curriculum that emphasizes content, takes time to prepare the learning situation and integrate it with the purpose of teaching long enough (Putnam \& Borko, 2000). The curriculum that emphasizes the situation, the time to prepare it is shorter, while the curriculum that emphasizes organizational 
preparation time is almost the same as the curriculum that emphasizes the content (Harden, Sowden, \& Dunn, 1984).

\section{Higher-Education Accountability: The Impact of Curriculum Policy Implementation}

Accountability in the context of universities covered six issues stating the questions as follows: (a) are the rules set by the university accountable? (b) are lecture materials given by lecturers accounted for in curricular and academic ethics? (c) are the test scores obtained by students? (d) is the attitude toward the services of university managers accounted for by law, ethics, religion, and cultural values? (e) are the researchers undertaken and the outcome compatible with religion and/or law? (f) does the college have a code of ethics? (Howieson, 2003).

\section{Head of Study Program as the Leader in Implementing KKNI-Based Curriculum in Islamic Higher Education Institutions}

\section{Heads of Study Program as a Direction Determiner}

The determination of the direction of higher-education curriculum based on KKNI, in the eight study programs, seems that the head of study program in directing the program has not been optimal. The chairman plays a role as a determinant of the direction of decision makers using the method of agreement with experienced people and corporate confidants, from all facilities and infrastructure available to the company. Strategies and tactics to lead the way of the company involve several employees. Such as the company's chiefs in the decision-making process through meetings. The leaders view that decisions made from meetings will be better because they are the result of some people's thoughts.

The head of study program also always asks directly to the lecturer to run the program. In this case the curriculum development program in order to benefit the students. The head of study program must optimize the utilization of all facilities and infrastructure.

\section{Heads of Study Program as Deputy and Organization Spokesman}

Dealing with coordinating the KKNI-based higher-education curriculum in the eight study programs, it seems that the heads of the study program have not been optimal in representing the project. As the representative and spokesperson, the head of the study program needs to know the decisions made by the deputy and need to know the decisions made by the section head. As the spokesperson, the head of the study program needs to convey and describe the information to outside parties even outside the company regarding the company's plans. The policies, measures, results and part of it are the duties of the head of section that exist as the leaders' representatives, if the leader is not in the company.

As a company spokesperson, the head of the study program needs to know the decisions that have been made. The policies and activities within the company described to outside parties are what are required by an outsider, the quality of the processed timber of the enterprise or its legal basis. The head of the study program runs a leadership role as a spokesperson, wherever it is needed, and the head of the study program must be in place (Wijaya \& Radianto, 2017).

\section{Heads of Study Program as an Effective Communicator}

Similarly, by communicating the KKNI-based higher-education curriculum program, in the eight study programs, it seems that the head of study program has not been effective in communicating it. The head of the study program carries out good relationships with employees through the communication process. He also submits decisions in controlling, supervising and conveying information to other parties. The communication done by the chairman was to connect with all lecturers and employees. Communication to employees should be done for the study program as well. Thus, the head of study program knows the problems that exist in the lecturer/employee and the problems that exist within the company. The interaction between 
the lecturers and employees to the study program is fine because in the study program, there has never been any problem with lecturers and employees.

The head of the study program carries out the outgoing and inward relationships by communicating, deciding in the context of controlling, supervising, and disseminating information with other parties. In the case of every decision making, it often involves employees, but there are lecturers/employees who do not want to get involved in decisionmaking with their reasons in terms of meetings even though the chairman of the study program has also firmly imposed sanctions (Ghina, 2014).

\section{Heads of Study Program as a Mediator}

Mediating the lecturers' understanding of the KKNI-based higher-education curriculum in eight study programs seems that the head of study program has not been optimal as its mediator. Chairman of the study program as a leader is always ready to resolve conflict situations that can be addressed from relationships both outside and inside the study program. Resolving conflict situations occur during the study program by deepening what happens by way of joint meetings at the company's completion. Anywhere or in other offices, the head of the study program must also run the challenges of conflict that occurred during the course of his studies.

The head of the study program should be able to communicate with the conflicting individual well, by giving the individual the opportunity to express his or her views of the conditions at hand. He resolves the conflict situation that occurs in the company. As a leader, he must carry out the challenges of conflict that occur within the company (Brown \& Duguid, 1991).

\section{Heads of Study Program as an Integrator}

Integrating the KKNI-based Higher-Education curriculum, in eight study programs, appears that the activities have not been well integrated yet. Indeed, the head of the study program is as an integrator to do the division of tasks, power allocation system, funds and labor in the program of study. It takes the atmosphere of a conducive work unit, full of kinship and cooperation that will make employees the spirit to work, which is inseparable from the role of corporate leaders in placing employees in the existing work. Each section has its own section head.

The head of study program clearly performs the division of duties of employees, power allocation system, fund courses and lecturers/employees as subordinates in the study program. The division of tasks, power allocation systems, funds and personnel within the company that managers do, only oversee the division of tasks that the secretary of the program studies does: fund courses used and discipline and employee performance (Tahernejad, 2016).

\section{Implementation of KKNI-Based Curriculum in Islamic Higher-Education Institutions}

It seems that the actors, developing the curriculum in the eight programs, have not yet understood how to bring on the changes and have not been able to ensure that the KKNI curriculum will bring the desired changes. Some research data show that: (1) the curriculum planning of the KKNI in the eight study programs has not determined the best possible situation of internal and external resource relationships in an educational system with a dynamic and efficient and effective way to achieve the intended objectives; (2) broadly speaking, the curriculum design in the eight study programs has not fulfilled the four elements, as determined by Law No. 12 Year 2012 on higher education, namely: (a) learning achievements, study materials to be mastered, (b) learning strategies to achieve, (c) the assessment system of its achievement, and (d) this brief guide; (3) The conditions in the eight study programs, have not clarified the expected "graduate profile" through study tracking, feasibility study and needs analysis in the community. Graduates' profiles reflect the minimum ability that students must master after graduation that refers to the four aspects of needs: (a) attitudes, (b) areas of 
workability, (c) knowledge, and (d) managerial and responsibility. The four priorities must then be translated into a learning outcome in each course in the course. Thus, all lessons plans or RPS (Rencana Pembelajaran Semester) should be based on learning outcomes in accordance with the needs of the graduate profile (Gupta, 2005).

\section{Factors Affecting the Implementation of Curriculum Policies}

Implementation of the curriculum in the eight programs has not been supported by factors that may affect its success due to some parameters. The parameters include (1) insufficient equipment and resources to apply the new curriculum; (2) the lack of time available to prepare and submit new curriculum requirements, for example, the lecturers need enough time to develop their understanding, with respect to the courses and teaching materials to be prepared; (3) the lack of support for lecturers, both from higher education, and from outside (ministries), such as the opportunity to receive continuous professional curriculum support; (4) lack of lecturers who have the ability and competence to deliver the material in accordance with the curriculum that is the belief to teach; (5) the lack of knowledge and understanding that lecturers have about the new curriculum, such as different learning methods to encourage students to learn and achieve higher achievements; and (6) lack of lecturer interest in new curriculum, such as sharpness and depth in teaching a course. These parameters have been discussed in literature (Harden et al., 1984).

In the case of the implementation of the curriculum, there are several influenced factors. The factors include: (1) the characteristics of the curriculum, including the scope of teaching materials, objectives, functions, properties and so on; (2) implementation strategies (i.e. strategies used in curriculum implementation such as professional discussions, seminars, upgrades, curriculum bookshop workshops and other activities that can encourage the use of curricula in the field); (3) the characteristics of the curriculum user, which includes the knowledge, skills, and values and attitudes of the teacher towards the curriculum in learning (Fullan \& Pomfret, 1977).

\section{The Impact of KKNI-Based Curriculum Policy Implementation}

Impact on the implementation of KKNI higher education curriculum in eight Islamic Education Studies Programs can be seen from two aspects. Firstly, it can be seen in terms of the impact of knowledge that has not been demonstrated. Secondly, it can be viewed from several indicators including: (1) the suitability between the program and beneficiaries; (2) the conformity between the program and the implementing organization; (3) the suitability between the beneficiary group and the implementing organization. This is in a good agreement with literature (Sayuti, 2016).

Secondly, when we viewed from the side from the impact of output, the quality produced has not shown any positive signs, as follows: (1) the application of curriculum-based curriculum KKNI in eight courses of PAI Kopertais Region II West Java-Banten belong to low category. This is because in the last three years, the average of score of students is still low; (2) the low average acquisition of students' score has an impact on the low performance on the study program, the acquisition of the average accreditation value is still low, has not reached the superior category. This condition implies that the performance on the study program has not been accountable. In fact, accountability is one of the vital management processes for the management of higher education, accountability plays a significant role as the parameters of professionalism in the implementation of higher education in its professional management. Therefore, to manage social institution of religion, there are three bases of phylopsophy: (1) the management pattern must be in the integrated project frame, (2) putting forward the welfare principle that balances between the obligations to be performed and the rights received, (3) the principle of transparency and accountability (Bergman, 2007). Accountability in higher- 
education institutions will have implications for the strengthening of social legitimacy. The legitimacy from the community will increase community support for the management of the institute.

\section{CONCLUSION}

The role of leadership of PTKIS in implementation of higher-education curriculum based on KKNI towards accountability of higher education has not been effectively implemented. Thus impacting the performance of PTKIS is not accountable due to several reasons: (1) the leadership of PTKIS, in this case, the eight Head of PAI Study Program has not been optimum to play its role as a determinant of direction, spokesman, communicator, mediator, and integrator in implementing KKNI higher education curriculum; (2) implementation of KKNIbased higher education curriculum in eight PAI Studies Programs has not been effectively implemented due to lack of communication, resources, disposition, and bureaucratic structure; (3) inadequate resources, time, work ethic, professional, professional knowledge, professional interests and attitudes, are inhibiting factors. The impact of the implementation of the KKNIbased higher-education curriculum, in the eight heads of PAI study programs, in terms of the impact of knowledge, there are several indicatirs as follows: (1) the suitability between the program and the beneficiaries, (2) the suitability between the program and the implementing organization, (3) the terms the organization decided to be able to obtain the output of the program with what the program target group can do. In terms of the impact of quality ouput produced has not shown, there are several indicators as follows: (1) ouput implementation performance of KKNI higher education based curriculum in eight PAI Study Programs Kopertais Region II Jabar-Banten, belongs to low category, because in last three years; the average of students' score are low; (2) The low average acquisition of students' score in the last three years has had an impact on the still low performance of the study program, because the accreditation scores in the eight of PAI Study Programs are still low. Although some students have the average score in the good category, but they did not yet entered at superior category. Thus, the accountability of a university is very important to maintain the quality of its graduates in the user community. The existence of certain advantages of the graduates is something that gives added value to the graduates, and the image of the college concerned. Especially in the development across the curriculum, it is entirely submitted to the college concerned so that in the future, the competition between the universities will be more stringent.

\section{BIBLIOGRAPHY}

Abdullah A. G., Sopian, W. W., Arasid, W., Nandiyanto, A. B. D., Danuwijaya, A. A., Abdullah, C. U. (in press). Short-term peak load forecasting using PSO-ANN methods: The case of Indonesia, Journal of Engineering, Science, and Technology.

Ainin, M. (1992). Fenomena demotivasi dalam pembelajaran Bahasa Arab di madrasah: Penyebab dan alternatif pemecahannya. Universitas, 5(S2), 31-46. Retrieved from http://mulok.library.um.ac.id

Amirrachman, A., Syafi'i, S., \& Welch, A. (2008). Decentralising Indonesian education: the promise and the price. World Studies in Education, 9(1), 31-53. Retrieved from https://link.springer.com/chapter/10.1007/978-90-481-2703-0_8

Asadullah, M. N. (2015). The effect of Islamic secondary school attendance on academic achievement. The Singapore Economic Review, 60(3), 1550052-1-1550052-24. https://doi.org/10.1142/S0217590815500526

Asadullah, M. N., Chakrabarti, R., \& Chaudhury, N. (2012). What determines religious school choice? Theory and evidence from rural Bangladesh. Bulletin of Economic Research, 67(2), 186-207. https://doi.org/https://doi.org/10.1111/j.1467-8586.2012.00476.x 
Barton, G. (1997). Indonesia's Nurcholish Madjid and Abdurrahman Wahid as intellectual Ulama: The meeting of Islamic traditionalism and modernism in neo-modernist thought. Islam and Christian-Muslim Relations, 8(3), 323-350. https://doi.org/10.1080/09596419708721130

Bergman, A. (2007). Co-constitution of domestic and international welfare obligations: The case of Sweden's social democratically inspired internationalism. Cooperation and Conflict: Journal of the Nordic International Studies Association, 42(1), 73-99. https://doi.org/10.1177/0010836707073477

Brown, J. S., \& Duguid, P. (1991). Organizational learning and communities-of-practice: Toward a unified view of working, learning, and innovation. Organization Science, 2(1), 4057. https://doi.org/10.1287/orsc.2.1.40

Chun, E., \& Evans, A. (2016). Rethinking cultural competence in higher education: An ecological framework for student development. ASHE Higher Education Report, 42(4), 7 162. https://doi.org/10.1016/S0022-3182(80)80003-3

Conger, J. A., \& Kanungo, R. N. (1987). Toward a behavioral theory of charismatic leadership in organizational settings. The Academy of Management Review, 12(4), 637-647. https://doi.org/10.5465/AMR.1987.4306715

Fullan, M., \& Pomfret, A. (1977). Research on curriculum and instruction implementation. Review of Educational Research, 47(2), 335-397. https://doi.org/10.3102/00346543047002335

Ghina, A. (2014). Effectiveness of entrepreneurship education in higher education institutions. Procedia-Social and Behavioral Sciences, 115, 332-345.

Gollwitzer, P. M. (1999). Implementation intentions: Strong effects of simple plans. American Psychologist, 54(7), 493-503. https://doi.org/https://dx.doi.org/10.1037/0003066X.54.7.493

Gupta, A. (2005). Securing the future of the Indian IT Industry: A case for educational innovation in Higher Technical Education--Challenges and the road ahead. Industry and Higher Education, 19(6), 423-431. https://doi.org/10.1007/978-3-319-43434-6_34

Hadijaya, Y. (2015). School based management at Matauli 1 State Senior High School Pandan. Researchers World, 6(4), 55-66. https://doi.org/http://dx.doi.org/10.18843/rwjasc/v6i4/08 SCHOOL

Harden, R. M., Sowden, S., \& Dunn, W. . (1984). Educational strategies in curriculum development: the SPICES model. Medical Education, 18, 284-297. https://doi.org/10.1111/j.1365-2923.1984.tb01024.x

Hashim, C. N., \& Langgulung, H. (2008). Islamic religious curriculum in muslim countries: The experiences of Indonesia and Malaysia. Bulletin of Education \& Research, 30(1), 1-19.

Higgins, K. P. (2009). A policy mystery: The passage of the 2004 school calendar changes bill (Doctoral dissertation, The University of North Carolina at Chapel Hill).

Howieson, B. (2003). Accounting practice in the new millennium: Is accounting education ready to meet the challenge? British Accounting Review (Vol. 35). https://doi.org/10.1016/S08908389(03)00004-0

Jennings, P. A., \& Greenberg, M. T. (2009). The prosocial classroom: Teacher social and emotional competence in relation to student and classroom outcomes. Review of Educational Research, 79(1), 491-525. https://doi.org/10.3102/0034654308325693

Klerkx, L., \& Aarts, N. (2013). The interaction of multiple champions in orchestrating innovation networks: Conflicts and complementarities. Technovation, 33, 193-210. https://doi.org/10.1016/j.technovation.2013.03.002 
Kozlowski, S. W. J. J., \& Ilgen, D. R. (2006). Enhancing the effectiveness of work groups and teams. Psychological Science in the Public Interest, 7(3), 77-124. https://doi.org/10.1111/j.15291006.2006.00030.x

Lukens-Bull, R. A. (2001). Two sides of the same coin: Modernity and tradition in Islamic Education in Indonesia. Anthropology \& Education Quarterly, 32(3), 350-372. https://doi.org/10.1525/aeq.2001.32.3.350

Mazmanian, D., \& Sabatier, P. (1980). Conceptual framework. Policy Studies Journal, 538-60.

Oliver, R., Kersten, H., Vinkka-puhakka, H., Alpasan, G., Bearn, D., Ceman(nci), I., ... D.White. (2008). Curriculum structure: Principles and strategy. European Journal of Dental Education, 12, 74-84. https://doi.org/10.1111/j.1600-0579.2007.00482.x.

Podzimek, K. (2014). Quality of life research on students with disabilities in Monrovia, Liberia (Doctoral dissertation, University of Maryland, College Park). Retrived from: https://drum.lib.umd.edu/bitstream/handle/1903/15296/Podzimek_umd_0117E_ 15102.pdf;sequence $=1$

Portin, B., Schneider, P., DeArmond, M., \& Gundlach, L. (2003). Making sense of leading schools: A study of the school principals. University of $W$ ashington. Washinton: University of Washington. Retrieved from papers2://publication/uuid/B0CAEF3A-CECB-47DF-B871807B7F390AF7

Putnam, R. T., \& Borko, H. (2000). What do new views of knowledge and thinking have to say about research on teacher learning? Educational Researcher, 29(1), 4-15. https://doi.org/10.3102/0013189X029001004

Rahman, M. M. (2010). Islamic micro-finance programme and its impact on rural poverty alleviation. International Journal of Banking and Finance, 7(1), 119-138. Retrieved from http://epublications.bond.edu.au/ijbf/vol7/iss1/7

Rany, S., Zain, A. N. M., \& Jamil, H. (2012). Establishment of institutional policies for enhancing education quality in Cambodian Universities. International Journal of Higher Education, 1(1), 112-127. https://doi.org/10.5430/ijhe.v1n1p112

Raybould, M., \& Wilkins, H. (2005). Over qualified and under experienced: Turning graduates into hospitality managers. International Journal of Contemporary Hospitality Management, 17(3), 203-216. https://doi.org/10.1108/09596110510591891

Sarros, J. C., Wolverton, M., Gmelch, W. H., \& Wolverton, M. L. (1999). Stress in academic leadership: US and Australian department chairs/heads. The Review of Higher Education, 22(2), 165-185.

Sayuti, M. (2016). The Indonesian competency standards in technical and vocational education and training: An Evaluation of policy implementation in Yogyakarta province Indonesia (Doctoral dissertation, The University of Newcastle Australia).

Schein, E. H. (2003). Organizational socialization and the profession of management. Organizational influence processes, 36(3), 283-294.

Shorish, M. M. (1988). The Islamic revolution and education in Iran. Comparative Education Review, 32(1), 58-75.

Shartle, C. L. (1946). Occupations in psychology. American Psychologist, 1(12), 559.

Stufflebeam, D. L. (2001). Evaluation models. New Directions for Evaluation, 89, 7-89. https://doi.org/10.1002/ev.1

Subotnik, R. F., Olszewski-Kubilius, P., \& Worrell, F. C. (2011). Rethinking giftedness and gifted education: A proposed direction forward based on Psychological Science. Psychological Science in the Public Interest, 12(1), 3-54. https://doi.org/10.1177/1529100611418056 
Tahernejad, A. (2016). Leadership and organizational commitment in teacher training universities in Iran: The moderating role of emotional intelligence (Doctoral dissertation, University of Malaya).

Walsh, J. P., Tushman, M. L., Kimberly, J. R., Starbuck, B., \& Ashford, S. (2007). On the relationship between research and practice: Debate and reflections. Journal of Management Inquiry, 16(2), 128-154. https://doi.org/10.1177/1056492607302654

Wijaya, O. Y. A., \& Radianto, W. E. (2017). Performance measurement in entrepreneurship education: Target as a key to success of business run by student. Jurnal Aplikasi Manajemen, 15(4), 683-692.

Ylimaki, R., \& Jacobson, S. (2013). School leadership practice and preparation: Comparative perspectives on organizational learning (OL), instructional leadership (IL) and culturally responsive practices (CRP). Journal of Educational Administration, 51(1), 6-23. https://doi.org/10.1108/09578231311291404 